\title{
Overweight among seafarers working on board merchant ships
}

\author{
Giulio Nittari ${ }^{1}$, Daniele Tomassoni ${ }^{2}$, Marzio Di Canio ${ }^{3}$, Enea Traini ${ }^{1}$, Isabel Pirillo ${ }^{1}$, Andrea Minciacchi ${ }^{3}$ \\ and Francesco Amenta ${ }^{1,3}$
}

\begin{abstract}
Background: Obesity and overweight represent a relevant risk factor for seafarer's health. The frequency and distribution of overweight and obesity among seafarers working on board of Italian flag ships were studied. Analysis was made on occupational medicine files collected, in the frame of health surveillance inspections, between 2013 and 2016 from Centro Internazionale Radio Medico (CIRM).

Methods: The data of nationality, age, weight, height, blood glucose and blood pressure values obtained from 1155 seafarers were analyzed. Body mass index (BMI) values were calculated and compared with data reported for the general population of the same nationality of seafarers examined.

Results: BMI values revealed a tendency to overweight, whereas blood glucose and systolic blood pressure values were in general in the normal range. Approximtely $40 \%$ of subjects investigated were overweight, and more than the $10 \%$ of them were obese. Underweight was noticeable only in $1.22 \%$ of crew members and $0.34 \%$ of officers. The $0.52 \%$ of subjects investigated was diabetic, and $2.68 \%$ were hypertensive. Seafarers, regardless their nationality and rank, showed a greater tendency to overweight and obesity compared with general population of the same ethnicity.

Conclusions: Due to the occurrence of overweight and obesity among seafarers, campaigns for promoting awareness of the phenomenon and on the danger of these conditions for health should be promoted. Specific initiatives to avoid the assumption of junk food and the organization of adequate spaces, times and programs for physical exercise sessions on board should be offered for keeping seafarers healthier.
\end{abstract}

Keywords: Obesity, Overweight, Seafarers, Systolic blood pressure, Blood glucose

\section{Background}

Overweight and obesity are very important issues in different countries, [1] mainly because these conditions are associated with other problems such as cerebrovascular and coronary diseases, and several other causes of death [2]. Obesity and metabolic syndrome are considered risk factors for dementia, and are associated with lower cognitive performance in population-based investigations [3-5]. Statistical studies conducted in 2014 indicated that 1.9 billion adults worldwide are overweight, and of the latter about 600 million are obese [6]. It is estimated that these statistics will increase in the coming years, especially in the United States [7] and in Europe [8].

\footnotetext{
* Correspondence: daniele.tomassoni@unicam.it

${ }^{2}$ School of Biosciences and Veterinary Medicine, University of Camerino, Via Gentile III Da Varano, 62032 Camerino, Italy

Full list of author information is available at the end of the article
}

The obesity condition develops when there is an excess of nutrients introduced, compared to those consumed, but the contribution of these factors is still quite misunderstood. Many studies have revealed that both the excess of energy intake and the reduction of energy expenditure can determine the onset of obesity $[9,10]$. The body requires energy to support physiological functions, and when we introduce calories equal to the amount needed by the body, weight tends to remain the same. Over time people tend to eat and drink more calories than they burn, and excess calories lead to overweight, and progressively to obesity [11]. Obesity is a known risk factor for various diseases [12, 13] and can be considered a multifactorial pathology, due to genetic conditions [14], endocrine problems [15], impaired thyroid function, and environmental factors [16].

Obesity is recognized as a cause of physical inability among seafarers. In addition to the influence on health,

(c) The Author(s). 2019 Open Access This article is distributed under the terms of the Creative Commons Attribution 4.0 International License (http://creativecommons.org/licenses/by/4.0/), which permits unrestricted use, distribution, and reproduction in any medium, provided you give appropriate credit to the original author(s) and the source, provide a link to the Creative Commons license, and indicate if changes were made. The Creative Commons Public Domain Dedication waiver (http://creativecommons.org/publicdomain/zero/1.0/) applies to the data made available in this article, unless otherwise stated. 
being overweight may represent a safety issue on board ships. For example, performing emergency operations may be difficult for overweight people, such as taking emergency exits or climbing on a rescue boat. In this regard, it has been reported that fatal accidents are more common in shipping industry than in construction industry and manufacturing industry [17]. This suggests that, due to the difficult working conditions, seafarers should be fit for working on ships, to be able to face the most dangerous situations. Body mass index (BMI) and age are closely associated with work ability [18]. The report "Consultation on Obesity", published in 1997, [19] by the World Health Organization (WHO) has reported an interesting system for classifying overweight and obesity. BMI system is used internationally [20] and is calculated by dividing the person's body weight (in kilograms) with the squared height (in meters). Based on the WHO classification, normal conditions are BMI values between 18.5 and 24.9. Values between 25 and 29.9 indicate overweight, and values between 30 and 34.9 indicate an obesity condition. Moreover, values $<18.5$ indicate an underweight condition [19].

Seafarers are a population at high risk of developing cardiovascular diseases and cancer [21]. For these workers, the ship is not only the working place, but a real living environment for quite long periods [22]. Many factors such as exposure to chemical substances, smoking, alcohol consumption and obesity increase the risk of developing tumors and cardiovascular diseases [23]. Several studies have shown that obesity and overweight are frequent conditions in seafarers $[24,25]$.

In this study we have evaluated the prevalence of overweight and obesity by calculating the BMI of seafarers working on Italian flag ships involved in long distance international routes, navigating the seas around the world. The purpose of this study was to investigate whether obesity can be considered as a risk factor for seafarers and to identify suitable corrective strategies. The data of BMI calculated in seafarers, were related to blood glucose and blood pressure levels, and compared to the values of general population of the same countries of the seafarers [26-29]. This information could give elements on us how life on board ships, characterized by easy access to food, determines a greater prevalence of overweight and obesity in seamen, especially in those coming from countries with more disadvantaged socio-economic conditions [30].

\section{Methods}

This retrospective study is based on measurements made as a part of occupational medicine examinations that should be compulsory twice a year on Italian flag ships. Data examined for the present study were collected by the Centro Internazionale Radio Medico (CIRM), the Italian Telemedical Maritime Assistance Service (TMAS), in the frame of health surveillance activities performed on board ships. This study has analyzed 1155 medical records, carried out between 2013 and 2016 on seafarers on board of 20 Italian flag ships. All medical data (including identity of seafarers) are stored in the CIRM database and there are not accessible to externals. Data were extracted from the data base by the authors of this study. This study was made according in the frame of project called Health Protection and Safety on Board Ships (acronym: HEALTHY SHIP) [31].

From the medical examination reports, data on seafarers' nationality, age, height, weight, blood glucose, blood pressure and the results of other basic medical tests were extrapolated. The seafarers receiving anti-hypertensive and hypoglycemic treatment were not considered in the statistical analysis (Table 1).

BMI values were calculated for each seafarer based on the anthropometric parameters reported in the medical records and classified according to the criteria proposed by WHO $[19,20]$. In view of the heterogeneity of ethnicity of seafarers undergoing occupational medicine examinations, data obtained were compared with the national statistics of their respective countries, to assess whether the lifestyle of seafarers could affect their normal weight conditions. The BMI distribution was compared by the $X_{1}^{2}$ test assuming data obtained from literature [26-29] as expected values.

The potential correlation between BMI with blood glucose and blood pressure levels was evaluated by comparing the data of these two parameters. The means of different parameters investigated were calculated from single subjects grouped per age or per rank and were expressed as means \pm S.E.M. The significance of the differences between the mean values was analyzed by analysis of variance (ANOVA). The correlation between age and physiological parameters were calculated by Pearson's test.

\section{Results}

Analysis included 1155 medical records. All seafarers examined were male, aged between 21 and 66 years (mean $39.00 \pm 11.38$ years). As per nationality, $37 \%$ of them were Italians; 29\% Indians; 22\% from Philippines; $11 \%$

Table 1 Seafarers under pharmacological treatment

\begin{tabular}{lll}
\hline Pharmacological treatment & $\mathrm{Nr}$ & $\%$ \\
\hline $\begin{array}{l}\text { Arterial Hypertension } \\
\text { Proparolol/Atenolol + Furosemide }\end{array}$ & 35 & $3.03 \%$ \\
$\begin{array}{l}\text { Portal Hypertension } \\
\text { Nadolol + nitrate/ Nadolol }\end{array}$ & 41 & $3.55 \%$ \\
$\begin{array}{l}\text { Type II Diabetes } \\
\text { Metphormine }\end{array}$ & 97 & $8.39 \%$ \\
Diabetes+ Hypertension & 6 & $0.52 \%$ \\
Total & 67 & $14.45 \%$ \\
\hline
\end{tabular}


Romanians and $1 \%$ from other origins. The distribution of the BMI, blood glucose and systolic blood pressure values of seafarers divided for their rank on board Officers or non officers, e.g. crew members), are summarized in Table 2.

Data did not show differences between officers and crew members in all parameters considered. Mean BMI values showed a general tendency to the overweight condition, whereas blood glucose and mean systolic pressure values were in the normal range (Table 2). The percentage of subjects whose parameters were beyond normal limits is summarized in Fig. 1.

Over $40 \%$ of all subjects examined (officers or non-officers) resulted overweight, and over 10\% (10.49\% crewmembers and $11.84 \%$ officers) were obese. Only $1.22 \%$ of crew members and $0.34 \%$ of officers resulted underweight (Fig. 1). Only $0.52 \%$ of subjects examined were diabetic $(0.52 \mathrm{crew}$ members, $0.51 \%$ officers $)$, and $2.68 \%$ (2.45\% crew, $2.92 \%$ officers) resulted hypertensive. No significant differences were found between the two rank groups considered.

The distribution of BMI, and the mean values for age are summarized in Fig. 2 a and b. A direct correlation was found between these two parameters (Table 3), with an increase of body weight with age mainly in subjects over 45 years. The same distribution was found both in crew members and officers (data not shown). Blood glucose (Fig. $2 \mathrm{c}$ and d) and systolic blood pressure (Fig. $2 \mathrm{E}$ and $\mathrm{F}$ ) values were independent from aging as confirmed by Pearson's correlation (Table 3).

Analysis of the correlations between age and the physiological parameters investigated by the Pearson's test, is shown in Table 3, whereas the correlation between BMI and blood glucose levels and systolic pressure levels is summarized in Table 4. Blood glucose levels slightly correlated with the BMI values, whereas systolic blood pressure values were independent from BMI (Table 4).

Data obtained were further analyzed and referred to the nationality of the seafarers. BMI values calculated for seafarers were also compared with those reported in the general population of the same ethnicity (country) groups.

The comparison of mean BMI value between seafarers and onshore population of the same nationality (from

Table 2 Distribution of parameters investigated among seafarers grouped per rank

\begin{tabular}{lllll}
\hline & No. & $\begin{array}{l}\mathrm{BMI} \\
\mathrm{Kg} / \mathrm{m}^{2}\end{array}$ & $\begin{array}{l}\text { BLOOD GLUCOSE } \\
\mathrm{mg} / \mathrm{dl}\end{array}$ & $\begin{array}{l}\text { SYSTOLIC PRESSURE } \\
\mathrm{mmHg}\end{array}$ \\
\hline Total & 1155 & $25.7 \pm 3.5$ & $96.2 \pm 11.7$ & $118.1 \pm 8.5$ \\
Officers & 583 & $25.9 \pm 3.5$ & $96.1 \pm 10.4$ & $118.1 \pm 8.5$ \\
Non officers & 572 & $25.5 \pm 3.5$ & $96.3 \pm 12.9$ & $118.0 \pm 8.4$
\end{tabular}

The data are the mean \pm S.D. obtained WHO database) revealed differences for Filipino and Indian populations. Filipino seafarers averaged a BMI of 24.7 whereas the same value in Filipino general population was 22.6. The same is true for our Indian seafarers with a BMI of 25.7 seafarers vs 21.5 onshore. Romanian seafarers had a BMI of 27.2, whereas this value for general population averaged 26.9. For Italians, BMI values were similar to the population of the respective countries (25.8 seafarers vs 26.9 onshore). The prevalence of seafarers in the different weight classes was also compared to the values of the population of the respective countries. As shown in Table 5, the percentage of overweight and obese subjects was higher in seafarers compared to the general population of the same country (Table 5). The Filipino seafarers examined in this study were more overweight (30.4\% versus $17.9 \%$ of the general population) or obese $(7.4 \%$ versus $3.0 \%$ of the general population) compared to the population of compatriots. [26] $41.2 \%$ of Indian seafarers were overweight and $11.8 \%$ of them were obese. These values are higher than those of the respective male population, accounting for $8.4 \%$ of overweight and only $1.3 \%$ of obesity. No significant differences in the values of overweight were noticeable in Italian seafarers compared to the Italian general population (Table 5), although among seafarers a slightly higher percentage of obesity compared to general population was noticeable (Table 4). In Romanian seafarers, overweight and obesity were similar than in the general population (Table 5). The differences in BMI distribution of seafarers compared to those of general population were statistically significant at the $\mathrm{X}^{2}$ test $(p<0.05)$ for Filipino, Indian and Romanian seafarers.

\section{Discussion}

This study has shown the occurrence of overweight and obesity among seafarers examined on board of Italian flag ships. Moreover, we have observed that male seafarers working on board Italian merchant ships gain excessive weight around the age of 39-45 years, and reach the highest BMI in the group of 55-66 years of age. The present epidemiological analysis was performed on a particular category of workers, the seafarers, whose life styles undergo significant conditioning, due to the fact that they work on board of ship for months.

Analysis of the physiological parameters of blood glucose and systolic blood pressure levels did not show a direct correlation with age. Although $2.68 \%$ of the subjects was diabetic and $0.52 \%$ hypertensive, the non-correlation between body weight increase, blood glucose levels and hypertension, would exclude a condition of metabolic syndrome in the seafarers examined. On the other hand, no significant differences in terms of overweight and obesity were found between officers and crew. In fact, $41.44 \%$ of officers and $40.21 \%$ of crew 


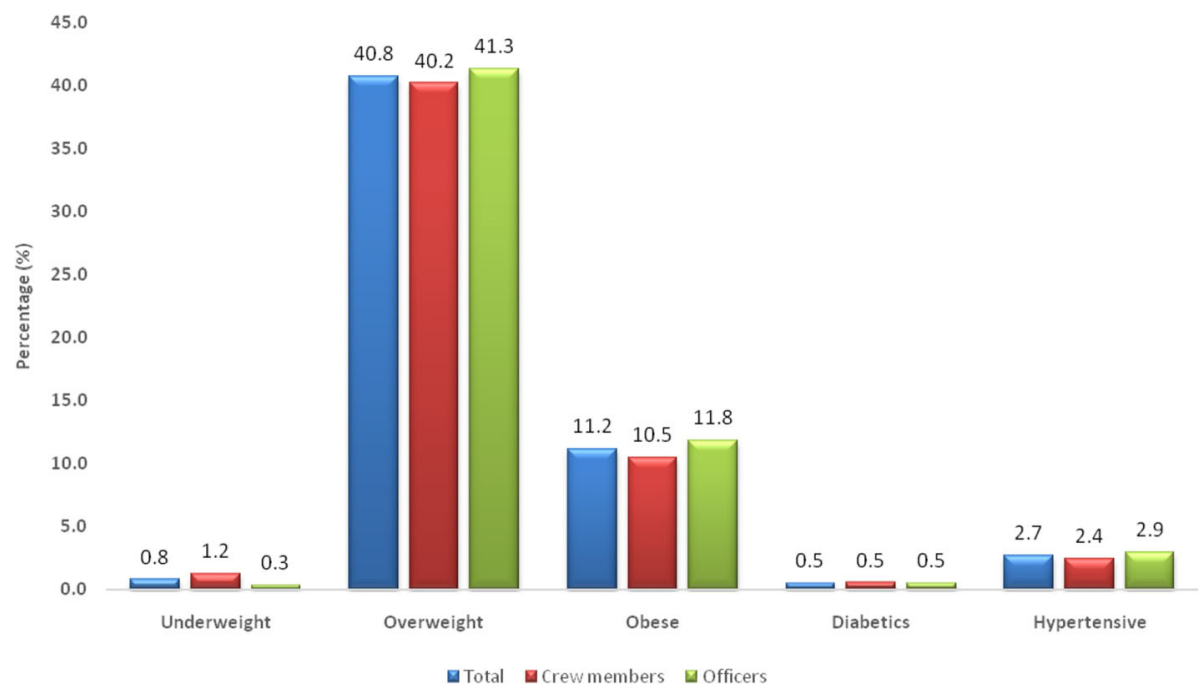

Fig. 1 Percentage of seafears, divided in general by rank (officers and non-officers, e.g. crew members) whose parameters were not within normal limits
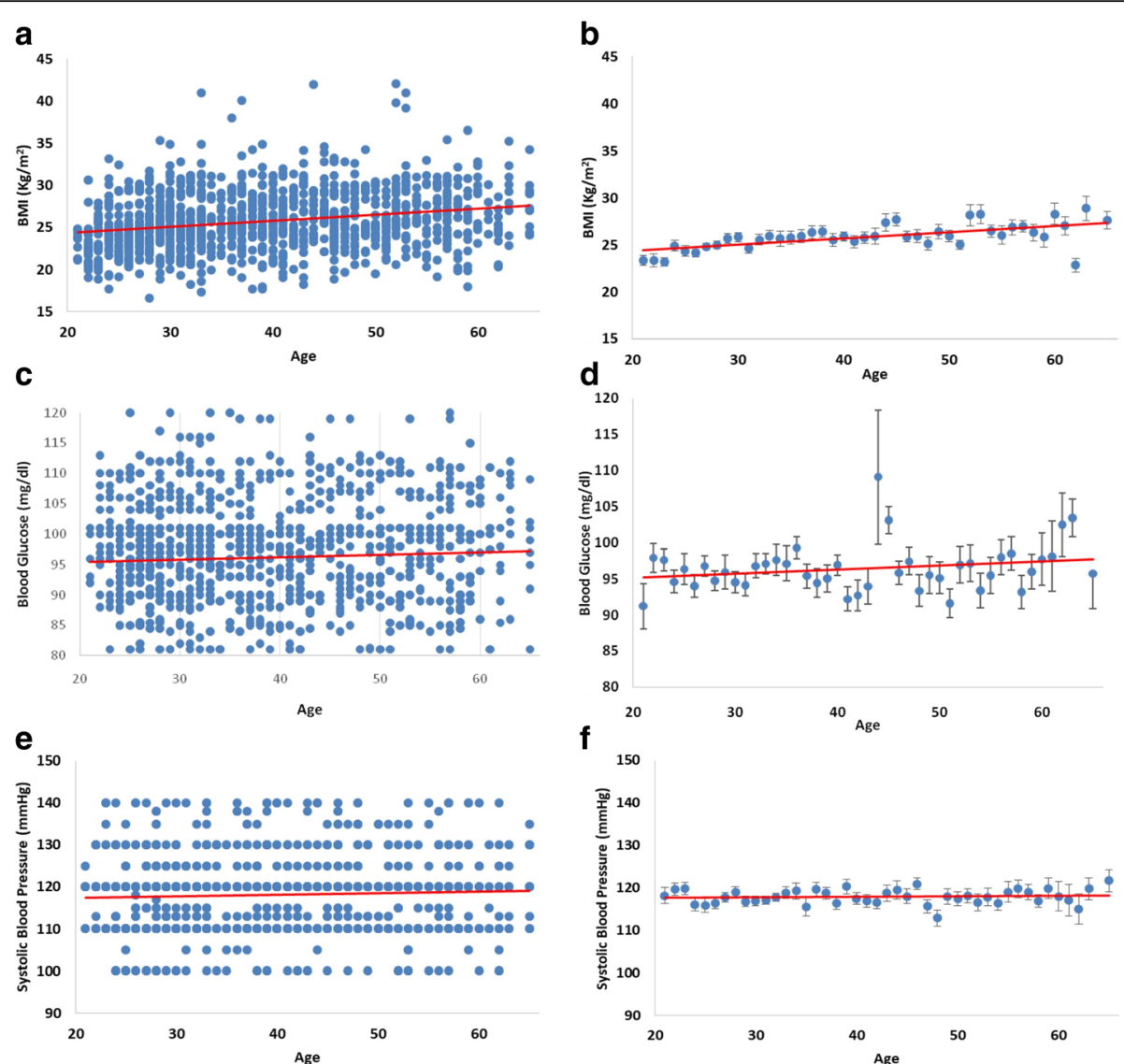

Fig. 2 a Scatterplot of body mass index $\left(B M I \mathrm{Kg} / \mathrm{m}^{2}\right)$ values by age of subjects examined. b Mean \pm S.E.M of BMI values for age. c Scatterplot of blood glucose $(\mathrm{mg} / \mathrm{dll})$ values by age of subjects examined. $\mathbf{d}$ Mean \pm S.E.M of blood glucose values for age. e Scatterplot of systolic blood pressure $(\mathrm{mmHg})$ values by age of subjects examined. $\mathbf{f}$ Mean \pm S.E.M of systolic blood pressure values for age 
Table 3 Pearson correlation coefficients and significance between age and physiological parameters examined

\begin{tabular}{lll}
\hline & Pearson Correlation & Significance \\
\hline BMI & & \\
Total & $0.23 \#$ & $8.88^{*} 10^{-16}$ \\
Crew members & $0.24 \#$ & $4.33^{*} 10^{-9}$ \\
Officers & $0.25 \#$ & $1.94^{*} 10^{-9}$ \\
Blood glucose & & \\
Total & 0.04 & 0.21 \\
Crew members & 0.02 & 0.70 \\
Officers & 0.06 & 0.12 \\
Systolic pressure & & \\
Total & 0.05 & 0.11 \\
Crew members & 0.03 & 0.43 \\
Officers & 0.06 & 0.13 \\
\hline
\end{tabular}

$\#=p<0.05$ in Pearson's test

members were overweight and $11.84 \%$ of officers and $10.49 \%$ of crew were obese. Despite the significant number of subjects studied in this work, it was not possible to correlate the results to the educational levels, the socio-economical conditions or to the physical activity, as these data are not considered in occupational medicine screenings of seafarers. Hence, these data were not available in the patients medical records.

Comparison of our data on excessive weight among seafarers embarked on Italian ships with the results of other studies (26-29) showed an undesirable weight pattern among seafarers, with a higher tendency to overweight and obesity in this category of workers.

The 254 Filipinos seafarers analyzed in this study showed a percentage of overweight and obesity respectively of $30.4 \%$ and $7.4 \%$. In the Filipino adult general population, over the age of 20 years, percentages of overweight and obesity were respectively 17.9 and 3.0\%. Filipino seafarers with a BMI $>25 \mathrm{~kg} / \mathrm{m}^{2}$ account for the $37.7 \%$ of the sample compared to $20.9 \%$ of the Philippines general population [26]. Out of the 335

Table 4 Pearson correlation coefficients and significance between $\mathrm{BMI}$ and physiological parameters examined

\begin{tabular}{lll}
\hline & Pearson Correlation & Significance \\
\hline Blood glucose & & \\
Total & $0.14 \#$ & $1.24^{*} 10^{-6}$ \\
Crew members & $0.12 \#$ & 0.003 \\
Officers & $0.17 \#$ & $4.65^{*} 10^{-5}$ \\
Systolic pressure & & \\
Total & 0.01 & 0.85 \\
Crew members & 0.01 & 0.81 \\
Officers & $8.20^{*} 10^{-4}$ & 0.98 \\
\hline
\end{tabular}

$\#=p<0.05$ in Pearson's test
Indian seafarers esamined in the study, $41.2 \%$ was overweight and $11.7 \%$ obese (Table 5). In the Indian adult general population (15-54 years), an $8.4 \%$ of overweight and $1.3 \%$ of obese individuals were reported. Indian seafarers who have a BMI $>25 \mathrm{~kg} / \mathrm{m}^{2}$ are $52.7 \%$, and therefeore they account for a significantly higher proportion compared to $9.7 \%$ of males of general population estimated by a study conducted by the International Institute for Population Science [27].

Italian seafarers with a BMI $>25 \mathrm{~kg} / \mathrm{m}^{2}$ were $40.6 \%$ of the total, compared to $39.8 \%$ of the Italian population. In contrast, obese Italian seafarers were more compared to the Italian male population [28]. Romanian seafarers with a $\mathrm{BMI}>25 \mathrm{~kg} / \mathrm{m}^{2}$ were $58.7 \%$ of the total, compared to $53.1 \%$ of the Romanian general population. Seafarers of the same nationality with a BMI $>30$ were $18.2 \%$, whereas obese individuals in the Romanian male general population averaged the $16.9 \%$ [29].

Overweight and underweight values in seafarers compared with those of the general population were higher in people living in lower income countries. A possible explanation of this observation is that the abundance of food on board stimulated exaggerated eating as a sort of rewarding versus a more limited availability in home countries. This excessive eating promotes overweight. This relationship is less obvious for obesity indicating that obesity has more complex causes than the simple overweight that could be promoted just by excessive eating. This hypothesis is supported indirectly by the observations that in Italian seafarers, coming from the country with the highest per capita income among the four analyzed in this work [30], no relevant differences in overweight and obesity percentages compared with general population were noticeable.

\section{Conclusion}

Our data show an increased tendency of being overweight and obese among seafarers, compared to the general population of the same ethnicity. This condition may be due to unhealthy lifestyles such as inappropriate diet, lack of fresh food in the diet, consumption of large quantity of sugared tea, coffee and beverages because of their odd working hours and unique lifestyle, lack of physical activity. Unfortunately, no data on diet and physical activities can be obtained from the electronic health records analyzed in this study. This prompted us to develop a specific lifestyle questionnaire that will be administered to seafarers, to obtain useful information about their lifestyle.

Other studies confirm the high incidence of overweight and obesity in American, Croatian and Danish seafarers. [32-34] In this context, the analysis carried out on a group of mariners revealed that about $80 \%$ of them is not satisfied with the quality of food available on 
Table 5 Body mass index percent distribution among seafarers of different nationalities compared with general population data of the same country

\begin{tabular}{|c|c|c|c|c|c|}
\hline & $\begin{array}{l}\text { Underweight } \\
(<18.5)\end{array}$ & $\begin{array}{l}\text { Healthy Weight } \\
(18.5-24.9)\end{array}$ & $\begin{array}{l}\text { Overweight } \\
(25-29.9)\end{array}$ & $\begin{array}{l}\text { Obese } \\
\geq 30\end{array}$ & $\begin{array}{l}\text { Overweight } \\
\text { \& Obese }\end{array}$ \\
\hline $\begin{array}{l}\text { Filipinos general population mean } \\
\text { [25] }\end{array}$ & $10.6 \%$ & $68.5 \%$ & $17.9 \%$ & $3.0 \%$ & $20.9 \%$ \\
\hline Filipinos seafarers & $1.2 \%$ & $61.1 \%$ & $30.4 \%$ & $7.4 \%$ & $37.7 \%$ \\
\hline Indian general population mean [26] & $33.7 \%$ & $56.6 \%$ & $8.4 \%$ & $1.3 \%$ & $9.7 \%$ \\
\hline Indian seafarers & $0.9 \%$ & $46.2 \%$ & $41.2 \%$ & $11.8 \%$ & $52.9 \%$ \\
\hline Italian general population mean [27] & $0.8 \%$ & $50,9 \%$ & $39.8 \%$ & $8.5 \%$ & $48,3 \%$ \\
\hline Italian seafarers & $1.6 \%$ & $46.4 \%$ & $40.6 \%$ & $11.4 \%$ & $52.0 \%$ \\
\hline Romanian general population mean [28] & $0.9 \%$ & $29.1 \%$ & $53.1 \%$ & $16.9 \%$ & $70.0 \%$ \\
\hline Romanian seafarers & 0 & $23.1 \%$ & $58.7 \%$ & $18.2 \%$ & $76.9 \%$ \\
\hline
\end{tabular}

read board and would like to eat healthier; $20 \%$ of them retain food in their cabin and approximately $20 \%$ of these seafarers use dietary supplements to overcome dietary gaps. Fresh products are also not often available on board [35].

During sea voyages, seafarers have no choice in terms of quality of food, and meals are influenced by the presence of different ethnicities [36]. Other studies in literature suggest that inappropriate nutrition on board is a widespread problem $[37,38]$. A survey based on the eating habits of Chinese seafarers showed a shortage of vitamin $\mathrm{C}$, vitamin $\mathrm{B} 2$, vitamin $\mathrm{A}$ and calcium based on a daily diet [39].

In general, seafarers have also insufficient levels of physical activity. A study carried out on a Norwegian group of seaman showed that $70 \%$ of them practiced physical exercise at home twice a week, whereas only $39 \%$ were used to training on board. Moreover, 20\% never performed physical exercise on board while only $5 \%$ of the sample did not practice sports even at home [40]. On the other hand, with the evolution of marine technology and equipment, onboard work is largely sedentary and requires minimal physical effort [41].

In view of the occurrence of overweight and obesity among seafarers, campaigns for promoting awareness of the phenomenon and on the danger for health of these conditions should be promoted. Specific initiatives to avoid the assumption of junk food, preferring healthy foods, ensuring fresh food supplies, adequate intake of vitamins and mineral salts, and regularizing meals on board should be undertaken. Organization of adequate spaces, times and programs for physical activity on board ships should also be offered for keeping seafarers healthier. Promotion of a correct and healthy lifestyle can reduce the incidence of overweight and related pathologies that likely will appear after the service on board ships (e.g. cardiac and cerebrovascular diseases). Management of overweight-related pathologies in an environment such as a ship at high sea may be difficult, taking into account that merchant ships have no physicians or expert health professionals on board as well as they are provided with limited medical facilities [42]. In view of this, prevention more than treatment of pathologies is the most reasonable strategy to pursue for protecting the health of a category of workers which, in general, receives less health protection than workers ashore.

\section{Abbreviation}

BMI: Body Mass Index; CIRM: Centro Internazionale Radio Medico; TMAS: Telemedical Maritime Assistance Service; WHO: World Health Organization

\section{Acknowledgments}

Authors are indebted to Mr. Antonio Arcese and Andrea Saturnino for their collaboration in collecting biomedical data of this work.

\section{Funding}

This work was supported by Foundation Centro Internazionale Radio Medico (C.I.R.M.), Rome, Italy, five per thousand (0.5\%) funding. The $0.5 \%$ funding is the possibility allowed by the Italian law that taxpayers devolve this percentage of their annual income tax return to a non-profit institution for social, health, phylantropic or research purposes. C.I.R.M. was eligible to $0.5 \%$ funding being a non-profit Foundation. Support to this work was given to design of the study, the collection, analysis, and interpretation of data.

\section{Availability of data and materials}

This retrospective study is based on measurements made as a part of occupational medicine examinations that should be compulsory done 2 times per year in Italian flag ships. Data examined for the present study were collected and stored in a closed database by the Centro Internazionale Radio Medico (CIRM), the Italian Maritime Telemedical Assistance Service (TMAS) in the frame of health surveillance activities performed on board ships. Data were extracted from the data base by CIRM operators and anonymized before being used for research purposes. CIRM President as legal representative of the entity where medical data are kept has authorized access to authors for collecting data of this work.

\section{Authors' contributions}

GN: he has made substantial contribution to conception and design of the study; he has analysed and revised the data; he prepared the draft of manuscript and revised it critically; he has given final approval of the version to be published. DT: he has made substantial contribution to conception and design of the study; he has analysed and revised the data; he prepared the draft of manuscript and revised it critically; He has given final approval of the version to be published. MDC: he has made substantial contribution to conception and design of the study. He has classified data and performed data collection from database of C.I.R.M. He has made the first part of 
statistical analysis of data. He has given final approval of the version to be published. ET: he has made substantial contribution to conception and design of the study; he performed advanced analysis statistical of data; has given final approval of the version to be published. IP: she has made substantial contribution to conception and design of the study; analysis of ethical implications; has given final approval of the version to be published. AM: he has made substantial contribution to conception and design of the study. He has visited part of seafarers and therefore collected medical data that represent the basis of this study. He has prepared and approved health records that are part of this study. He supervised data transfer in the database of C.I.R.M.; he has given final approval of the version to be published. FA: he has directed and coordinated the study making substantial contribution to conception and design of the study; ha he has performed part of medical visits from which data of the present study were derived; he has given final approval of the version to be published.

\section{Ethics approval and consent to participate}

This study was made in the frame of the project "Health Protection and Safety on Board Ships" (acronym: HEALTHY SHIP).

It was submitted to the Ethic, Scientific and Medical Committee of CIRM Foundation that approved it (Approval No. 01/2013 of 31 January 2013). Seafarers gave their written informed consent to the CIRM for the treatment of their medical data as well as for the use of these data in anonymous form for research purposes, related to investigate health conditions of seafarers and for epidemiological studies. The above Ethic Committee approved the method of consent and the consent form to propose to seafarers.

\section{Consent for publication}

\section{Not Applicable.}

\section{Competing interests}

Authors declare do not have actual or potential competing financial interests and they were free to design, conduct, interpret, and publish this work without the intervention of any controlling sponsor.

\section{Publisher's Note}

Springer Nature remains neutral with regard to jurisdictional claims in published maps and institutional affiliations.

\section{Author details}

${ }^{1}$ Telemedicine and Telepharmacy Centre, University of Camerino, Via Madonna delle Caerceri, 9, 62032 Camerino, Italy. ${ }^{2}$ School of Biosciences and Veterinary Medicine, University of Camerino, Via Gentile III Da Varano, 62032 Camerino, Italy. ${ }^{3}$ Research Department, International Radio Medical Centre (CIRM), Via Dell'Architettura, 41, 00144 Rome, Italy.

Received: 7 February 2018 Accepted: 27 December 2018

Published online: 09 January 2019

\section{References}

1. World Health Organization. Obesity: preventing and managing the global epidemic. Report of a WHO consultation. World Health Organ Tech Rep Ser. 2000:894:1-253.

2. Frisardi $V$, Solfrizzi $V$, Seripa D, et al. Metabolic-cognitive syndrome: a crosstalk between metabolic syndrome and Alzheimer's disease. Ageing Res Rev. 2010;9:399-417. https://doi.org/10.1016/j.arr.2010.04.007.

3. Frisardi V, Imbimbo BP. Metabolic-cognitive syndrome: metabolic approach for the management of Alzheimer's disease risk. J Alzheimers Dis. 2012; 30(Suppl 2):S1-4. https://doi.org/10.3233/JAD-2012-120811.

4. Belsky DW, Caspi A, Goldman-Mellor S, et al. Is obesity associated with a decline in intelligence quotient during the first half of the life course? Am J Epidemiol. 2013;178:1461-8. https://doi.org/10.1093/aje/kwt135.

5. Ricci G, Pirillo I, Tomassoni D, et al. Metabolic syndrome, hypertension, and nervous system injury: epidemiological correlates. Clin Exp Hypertens. 2017; 39:8-16. https://doi.org/10.1080/10641963.2016.1210629.

6. WHO (2010), Global Status Report on Noncommunicable Disaeases. http:// www.who.int/nmh/publications/ncd_report2010/en/ (accessed 30 Apr 2017)

7. Manson JE, Bassuk SS. Obesity in the United States: a fresh look at its high toll. JAMA. 2003;289:229-30.

8. Silventoinen K, Sarlio-Lähteenkorva S, Koskenvuo M, et al. Effect of environmental and genetic factors on education-associated disparities in weight and weight gain: a study of Finnish adult twins. Am J Clin Nutr. 2004:80:815-22.

9. Kant AK, Graubard BI. Secular trends in patterns of self-reported food consumption of adult Americans: NHANES 1971-1975 to NHANES 1999-2002. Am J Clin Nutr. 2006:84:1215-23.

10. Dietz WH Jr, Gortmaker SL. Do we fatten our children at the television set? Obesity and television viewing in children and adolescents. Pediatrics. 1985;75:807-12.

11. Ozcirpici B, Coskun F, Sahnoz S, et al. Obesity prevalence in Gaziantep, Turkey. Ind J Comm Med. 2009;34:29-34. https://doi.org/10.4103/0970-0218.45371.

12. Barkin SL, Heerman WJ, Warren MD, et al. Millennials and the world of work: the impact of obesity on health and productivity. J Business Psychol. 2010; 25:239-45. https://doi.org/10.1007/s10869-010-9166-5.

13. Kovesdy CP, Furth SL, Zoccali C. World Kidney Day Steering Committee. Obesity and kidney disease: hidden consequences of the epidemic. Future Sci OA. 2017;3(3):FSO159. https://doi.org/10.4155/fsoa-2016-0081.

14. National Institutes of Health. Clinical guidelines on the identification, evaluation, and treatment of overweight and obesity in adults: The evidence report. National Heart, Lung, and Blood Institute; 1998. NIH Publication No. 98-4083.

15. Roberts SE, Nielsen D, Kotlowski A, et al. Fatal accident and injuries among merchant seafarers worldwide. Occup Med (Lond). 2014:64:259-66.

16. Grund SM. Multifactorial causation of obesity: implications for prevention. Am J Clin Nutr. 1998:67:563S-72S.

17. Andela CD, Van Haalen FM, Ragnarsson O, et al. Mechanisms in endocrinology: Cushing's syndrome causes irreversible effects on the human brain: a systematic review of structural and functional magnetic resonance imaging studies. Eur J Endocrinol. 2015;173:R1-14. https://doi. org/10.1530/EJE-14-1101.

18. Bridger RS, Bennett Al. Age and BMI interact to determine work ability in seafarers. Occup Med (Lond). 2011;61:157-62. https://doi.org/10.1093/ occmed/kqr003.

19. World Health Organization. Obesity. Geneva: Preventing and Managing the Global Epidemic; 1997

20. Flegal KM, Kit BK, Orpana H, Graubard BI. Association of allcause mortality with overweight and obesity using standard body mass index categories a systematic review and meta-analysis. JAMA. 2013;309:71-82. https://doi.org/ 10.1001/jama.2012.113905.

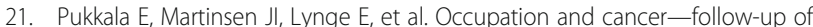
15 million people. Acta Oncol. 2009;48:646-790. https://doi.org/10.1080/ 02841860902913546

22. Nittari G, Peretti A, Sibilio F, et al. Development of software for handling ship's pharmacy. Int Marit Health. 2016;67:72-8. https://doi.org/10.5603/IMH. 2016.0015.

23. Oldenburg M, Baur X, Schlaich C. Occupational risks and challenges of seafaring. J Occup Health. 2010;52:249-56.

24. Nas S, Fişkın R. A research on obesity among Turkish seafarers. Int Marit Health. 2014:65:187-91.

25. Hansen $\mathrm{HL}$, Hjarnoe L, Jepsen JR. Obesity continues to be a major health risk for Danish seafarers and fishermen. Int Marit Health. 2011:62:98-103.

26. Baltazar JC, Baquilod MM. Second National Diabetes Survey- Phase 1: Philippines. Department of Health-University of the Philippines; 2002.

27. International Institute for Population Science (IIPS), ORC Macro. National family health survey (NFHS-3), 2005-06: India. 2007.

28. Gallus S, Odone A, Lugo A, et al. Overweight and obesity prevalence and determinants in Italy: an update to 2010. Eur J Nutr. 2013:52:677-85. https:// doi.org/10.1007/s00394-012-0372-y.

29. World Health Organization (WHO). Nutrition, physical activity and obesity Romania. 2013: 1-4

30. World Economic Outlook Database, January 2018, International Monetary Fund. Database updated on October 2017. Accessed on 25 September 2018.

31. Amenta F, Carotenuto A, Grappasonni I et al. Healthy Ship: an innovative project for health care improvement and health promotion on board ships. Med-e-Tel 2011 Proceedings of the International eHealth, Telemedicine and Health ICT Forum for Education, Networking and Business. Jordanova M, Lievens F ed. April 6-8, 2011 Luxembourg, G.D. of Luxembourg, pp.708-711.

32. Scovill SM, Roberts TK, McCarty DJ. Health characteristics of inland waterway merchant marine captains and pilots. Occup Med (Lond). 2012;62:638-41. https://doi.org/10.1093/occmed/kqs156.

33. Pancic M, Ricka-Zauhar Z, Blazevic M. Analysis of risk factors and assessment of exposure to coronary diseases in seamen. $8^{\text {th }}$ international symposium of maritime health, Rijeka, Croatia. 2005. 
34. Hansen H, Dahl S, Bertelsen B, et al. Lifestyle, nutritional status and working conditions of Danish sailors. Travel Med Int. 1994;12:139-43.

35. Witkowski C. Ernährung auf seeschiffen in der Kauffahrteischifffahrt [Nutrition onboard seagoing merchant vessels]: Bachelorarbeit Sommersemester 2011. https://www.worldcat.org/title/ernahrung-aufseeschiffen-in-der-kauffahrteischifffahrt-bachelorarbeit-sommersemester2011/oclc/969436125.

36. Oldenburg M, Harth V, Jensen HJ. Overview and prospect: food and nutrition of seafarers on merchant ships. Int Marit Health. 2013;64:191-4.

37. Ladunkoznawstwa K T, Wyzsza Szkola Morska G.; assessment of nutrition of seamen and fishermen. Rocz Panstw Zakl Hig, 1998:49: 499-505.

38. Ponomareva AG, Vasil'Eva TV. Factual nutrition of seamen of the North Sea steam navigation. Vopr Pitan. 1990;5:62-4.

39. Zhu J. "The influence of seafarers'malnutrition upon maritime safety." IAMU: the 7th annual general assembly. China: Dalian; 2006

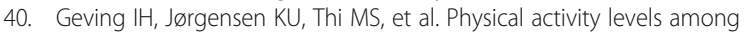
offshore fleet seafarers. Int Marit Health. 2007;58:103-14.

41. Ekholm O, KjAller M, Davidsen M. et al.; Sundhed og syge-lighed i danmark 2005 \& udviklingen siden 1987. National Public Health Institute, Copenhagen 2006

42. Ricci G, Pirillo I, Rinuncini C, et al. Medical assistance at the sea: legal and medico-legal problems. Int Marit Health. 2014;65:205-9. https://doi.org/10. 5603/IMH.2014.0039

Ready to submit your research? Choose BMC and benefit from:

- fast, convenient online submission

- thorough peer review by experienced researchers in your field

- rapid publication on acceptance

- support for research data, including large and complex data types

- gold Open Access which fosters wider collaboration and increased citations

- maximum visibility for your research: over $100 \mathrm{M}$ website views per year

At BMC, research is always in progress.

Learn more biomedcentral.com/submissions 